\title{
Internal Exposure in Nuclear Medicine: Application of IAEA Criteria to Determine the Need for Internal Monitoring
}

\author{
Bernardo Maranhão Dantas ${ }^{*}$, Eder Augusto de Lucena and Ana Letícia Almeida Dantas \\ Instituto de Radioproteção e Dosimetria; Av. Salvador Allende, s/n; 22780-160; bmdantas@ird.gov.br; Rio de \\ Janeiro - RJ - Brasil
}

\begin{abstract}
The manipulation of unsealed sources in nuclear medicine poses significant risks of internal exposure to the staff. According to the International Atomic Energy Agency, the radiological protection program should include an evaluation of such risks and an individual monitoring plan, assuring acceptable radiological safety conditions in the workplace. The IAEA Safety Guide RS-G-1.2 recommends that occupational monitoring should be implemented whenever it is likely that committed effective doses from annual intakes of radionuclides would exceed $1 \mathrm{mSv}$. It also suggests a mathematical criterion to determine the need to implement internal monitoring. This paper presents a simulation of the IAEA criteria applied to commonly used radionuclides in nuclear medicine, taking into consideration usual manipulated activities and handling conditions. It is concluded that the manipulation of ${ }^{131}$ I for therapy presents the higher risk of internal exposure to the workers, requiring the implementation of an internal monitoring program by the Nuclear Medicine Centers.
\end{abstract}

Keywords: nuclear medicine, internal monitoring, radiation protection

\section{INTRODUCTION}

Among the most widely used radionuclides in the field of nuclear medicine, the following should be highlighted: ${ }^{99 \mathrm{~m}} \mathrm{Tc},{ }^{131} \mathrm{I},{ }^{123} \mathrm{I},{ }^{201} \mathrm{Tl}$ and ${ }^{153} \mathrm{Sm}$. The activities manipulated annually in Brazil are in the order of hundreds of millicuries $(\mathrm{MBq})$ in about 300 nuclear medicine centers in routine operation (Alves, 2004). The Brazilian Nuclear Regulatory Board (CNEN) requires that an evaluation of the occupational risks must be performed prior to the start of operation of the installation, i.e., during the phase of licensing, so that there is a clear justification for the use of radioactive materials (CNEN, 2005)

Although it is recognized that in nuclear medicine centers external exposure is usually higher than internal exposure, the risks associated with intakes should be estimated in each case and, if necessary, workers involved in the manipulation of unsealed sources should be routinely monitored in order to demonstrate that individual doses are kept as low as possible. Internal monitoring should also be performed in response to an accidental or suspected inhalation or ingestion intake.

In general, the decision to enroll a worker in an internal monitoring program should be based on

\footnotetext{
* Author for correspondence
} 
the likelihood that the individual could receive an intake of radioactive material exceeding a predetermined level. The need for individual or area monitoring for internal exposure will depend on the quantity and type of radioactive material present, the physical and chemical form of the radioactive material, the type of containment used, the operations performed and the general working conditions. It can be difficult to determine whether monitoring a worker for intakes of radioactive material is necessary. Such monitoring should be used routinely only for workers in designated controlled areas where contamination may be present and potential exists for a significant intake to occur. (IAEA, 1999).

This work describes an application of the criteria suggested by the IAEA to determine whether an internal monitoring program is needed for nuclear medicine workers and discusses situations where monitoring is necessary and feasible.

\section{MATERIALS AND METHODS}

The criteria suggested by the IAEA to determine the need for monitoring is based on the calculation of the decision factor $\left(\mathrm{d}_{\mathrm{j}}\right)$, which takes into consideration safety factors related to the complexity of the task, handling conditions of the radioactive material, as well as the physical and chemical properties of the nuclide. IAEA criteria consider internal monitoring is necessary whenever the value of $d_{j}$ is above $1 \mathrm{mSv}$. The value of $d_{j}$ is calculated by the following equation:

$d_{j}=\sum_{j} 10 \cdot A_{j} \cdot e(g)_{j i n h} \cdot f_{h s} \cdot f_{p s}$

where $A_{j}$ is the quantity $(B q)$ of radionuclide type $j$ used in one year, $\mathrm{e}(\mathrm{g})_{\text {jinh }}$ is the dose coefficient $\left(\mathrm{mSv} \mathrm{Bq}{ }^{-1}\right)$ for inhalation of the radionuclide, and $\mathrm{f}_{\mathrm{hs}}$ and $\mathrm{f}_{\mathrm{ps}}$ are factors related to radiological safety conditions present in the workplace. The final value of $d_{j}$ is a summation that includes all the various types and forms of radionuclides used in the facility as well as the prevailing safety conditions during administration. All the parameters necessary to calculate $d_{j}$ are provided in the IAEA Safety Guide RS-G-1.2.

This methodology can also be used to calculate the maximum annual activity ( $\left.\mathbf{A}_{\text {máx }}\right)$ for which an internal monitoring plan is recommended for a specific radionuclide. This calculation is made by isolating the term $A_{j}$ and attributing the value of 1 $\mathrm{mSv}$ to the parameter $\mathrm{d}_{\mathrm{j}}$. It is important to note that the calculation of $\mathbf{A}_{\text {máx }}$ should only be applied to situations when only one single radionuclide is manipulated, or the contribution of the intake of other radionuclides in the workplace is assumed to be negligible.

$\mathrm{A}_{\text {máx }}=1 / 10 . \mathrm{e}(\mathrm{g})_{\text {jinh }} \cdot \mathrm{f}_{\mathrm{hs}} \cdot \mathrm{f}_{\mathrm{ps}}$

The values of the parameters $f_{h s}$ and $f_{p s}$ used in the simulations presented in this work for the calculation of $d_{j}$ and $A_{\text {máx }}$ where chosen in order to represent the radiation protection requirements for nuclear medicine centers defined by the Brazilian Nuclear Regulatory Board in the regulation 3.05 (CNEN, 1996). The operations involving handling of radionuclides in nuclear medicine can be classified as follows: elution, dose fractionation, labeling, dose administration and waste management. The elution step applies only to the radionuclide ${ }^{99 \mathrm{~m}} \mathrm{Tc}$. The other steps apply to all radionuclides considered in the simulations.

The manipulation factors $\left(\mathrm{f}_{\mathrm{hs}}\right)$ applied to the field of nuclear medicine can assume values of 0.1 and 1 depending on the type of operation being carried out, which can be considered as "very simple wet operation" or "normal chemical process". Values for the protection factor $\left(f_{p s}\right)$ are equal to 0.1 or 1 for radionuclides handled in a fume hood or on an open bench, respectively. For the simulation presented in this paper a "very simple wet operation" is performed in a fume hood. Thus, $\mathrm{f}_{\mathrm{hs}}$ and $f_{p s}$ are both equal to 0.1 which is a safe condition for handling unsealed sources of radioactive materials. It is important to highlight the fact that, according to the proposed criteria, the manipulation on an open bench increases the risk of incorporation by one order of magnitude.

The values of $e(g)_{j i n h}$ used in the calculations of $d_{j}$ are based on biokinetic and dosimetric models released by the International Commission on Radiological Protection (ICRP) and have been generated by the software AIDE (Activity and Internal Dose Estimate) (Bertelli et al., 2008). This software has been licensed by the IAEA for distribution among Latin America participant countries on the IAEA-ARCAL project entitled "Harmonization of Internal Dosimetry Procedures" (Melo et al., 2007). Default values refer to inorganic compounds in chemical forms prior to radiopharmaceutical labeling. 


\section{RESULTS}

The values of annual activities of each radionuclide used in the calculations of $\mathrm{d}_{\mathrm{j}}$ presented in this work where obtained through a survey performed in all nuclear medicine centers in operation in Brazil during the year of 2002. These values correspond to the minimum value of activity of each radionuclide manipulated annually in Brazil among all nuclear medicine centers in operation at that time. It is not likely that significant changes have occurred since 2002 in annual activities. Table 1 presents the range of annual activities authorized by the Brazilian Regulatory Boards to be manipulated in the Nuclear Medicine Centers in operation in Brazil. Table 2 presents the results of the simulation for calculating the decision factors $\left(d_{j}\right)$ as well as the maximum activities $\left(\mathrm{A}_{\text {máx }}\right)$ of each radionuclide of interest from which it is recommended to carry out a routine control of internal exposure of the staff through the implementation of an internal monitoring plan.
It can be observed that the $d_{j}$ corresponding to the lower activities of ${ }^{131} \mathrm{I}$ and ${ }^{153} \mathrm{Sm}$ are still above $1 \mathrm{mSv}$. On the other hand, all $\mathrm{A}_{\max }$ values are below the upper limit of the range of authorized activities. In the cases of ${ }^{131} \mathrm{I}$ and ${ }^{153} \mathrm{Sm}, \mathrm{A}_{\max }$ values are also below the lower values of authorized activities. In all other cases, i.e., ${ }^{123} \mathrm{I}$, ${ }^{201} \mathrm{Tl}$ and ${ }^{99 \mathrm{~m}} \mathrm{Tc}, \mathrm{A}_{\max }$ values are between the respective upper and lower values of the range of activities manipulated in Brazil.

Besides the application of the IAEA criteria for supporting the decision on the need for monitoring, such criteria can also be used to prioritize the practices to be controlled in relation to the occupational risk of internal contamination. In this case it is observed that ${ }^{131} \mathrm{I}$ presents the higher risk. Considering the proposed scenario, internal monitoring of ${ }^{131} \mathrm{I}$ should be included in the radiological protection plan, especially when used in therapeutic applications where the quantity of activity administered to each patient is usually several tens of millicuries.

Table 1 - Range of activities manipulated in Brazilian Nuclear Medicine Centers.

\begin{tabular}{ccc}
\multirow{2}{*}{ Nuclide } & \multicolumn{2}{c}{ Annual Activity Range (MBq) } \\
\cline { 2 - 3 } & Lower & Upper \\
\hline${ }^{131} \mathrm{I}$ & $7.80 \times 10^{3}$ & $7.80 \times 10^{6}$ \\
${ }^{153} \mathrm{Sm}$ & $3.90 \times 10^{4}$ & $1.98 \times 10^{6}$ \\
${ }^{123} \mathrm{I}$ & $1.98 \times 10^{4}$ & $1.98 \times 10^{5}$ \\
${ }^{201} \mathrm{Tl}$ & $7.80 \times 10^{3}$ & $4.63 \times 10^{5}$ \\
${ }^{99 \mathrm{~m}} \mathrm{Tc}$ & $4.84 \times 10^{5}$ & $1.98 \times 10^{7}$ \\
\hline
\end{tabular}

Table 2 - Values of $d_{j}$ and $A_{\max }$ according to IAEA Safety Guide RS-G-1.2 for selected radionuclides manipulated routinely in Nuclear Medicine Centers in Brazil Proposed scenario: very simple wet operation_performed in a fume $\operatorname{hood}\left(\mathrm{f}_{\mathrm{hs}}\right.$ and $\left.\mathrm{f}_{\mathrm{ps}}=0.1\right)$.

\begin{tabular}{cccccc}
\hline Nuclide & $\mathbf{e}(\mathbf{g})_{\text {inh }}(\mathbf{S v} / \mathbf{B q})$ & $\begin{array}{c}\mathbf{A}_{\mathbf{j m i n}} \\
(\mathbf{M B q})\end{array}$ & $\begin{array}{c}\mathbf{d}_{\mathbf{j}} \\
(\mathbf{m S v})\end{array}$ & $\begin{array}{c}\mathbf{A}_{\mathbf{m a x}} \\
(\mathbf{M B q})\end{array}$ & $\begin{array}{c}\mathbf{A}_{\mathbf{m a x}} \\
(\mathbf{m C i})\end{array}$ \\
\hline${ }^{131} \mathrm{I}$ & $1.98 \times 10^{-8}$ & $7.80 \times 10^{3}$ & $1.54 \times 10^{1}$ & $5.00 \times 10^{-2}$ & 13.7 \\
${ }^{153} \mathrm{Sm}$ & $2.96 \times 10^{-10}$ & $3.90 \times 10^{4}$ & $1.15 \times 10^{0}$ & $3.38 \times 10^{4}$ & 913 \\
${ }^{123} \mathrm{I}$ & $2.13 \times 10^{-10}$ & $1.98 \times 10^{4}$ & $4.22 \times 10^{-1}$ & $4.69 \times 10^{4}$ & 1269 \\
${ }^{201} \mathrm{Tl}$ & $7.68 \times 10^{-11}$ & $7.80 \times 10^{3}$ & $5.99 \times 10^{-2}$ & $1.30 \times 10^{5}$ & 3519 \\
${ }^{99 \mathrm{~m}} \mathrm{Tc}$ & $2.03 \times 10^{-11}$ & $4.84 \times 10^{5}$ & $9.83 \times 10^{-1}$ & $4.93 \times 10^{5}$ & 13314 \\
\hline
\end{tabular}

* Lower value of activities manipulated; **Activity related to $\mathrm{a}_{\mathrm{j}}=1 \mathrm{mSv}$. 


\section{DISCUSSION}

Calculation of the committed effective dose equivalent for workers due to the incorporation of radiopharmaceuticals requires specific biokinetic models that were not developed in this work. Such models are required to interpret results of in vivo and in vitro bioassay measurements if the intake occurred after the labeling step. Other computational codes are commercially available for such dose assessment. Alternatively, a specific biokinetic model can be developed for the radiopharmaceutical of interest by using the editing feature available in the AIDE software.

Direct application of the criteria suggested in the IAEA Safety Guide RS-G-1.2 would likely require internal monitoring for most of the workers in the field of nuclear medicine, representing a high cost on this practice in Brazil. Even if less restrictive parameters suggested in the IAEA safety guide were adopted in the calculation of $\mathrm{d}_{\mathrm{j}}$, it is likely that internal monitoring would be required.

For example, it would be necessary to implement internal monitoring plans in all facilities where the annual quantity of ${ }^{131} \mathrm{I}$ activity handled exceeded $13.7 \mathrm{mCi}(506.9 \mathrm{MBq})$. Considering the high costs necessary to comply with such requirements, it is strongly suggested that additional studies be conducted to improve the methodology for evaluating risks of internal contamination by the workers involved in the manipulation of unsealed sources. These studies should include a comprehensive national survey of worker exposures determined by in vivo and in vitro bioassay as well as aerosol sampling in radiopharmacy laboratories to provide actual data to evaluate risks associated with the practice of nuclear medicine.

A comparative approach based on the exposure scenarios and safety conditions adopted in this work indicates that the use of ${ }^{131} \mathrm{I}$ presents the higher risk of intake by workers. However, due to costs associated with transporting workers or bioassay samples to laboratories for analysis, it is suggested that the nuclear medicine centers use their own diagnostic devices to perform the monitoring of the workers (Dantas, 2007; Vidal, 2007; Lucena, 2007). Since the occupationally exposed group with higher risk of intake are most likely professionals who work in the radiopharmacy laboratories of the nuclear medicine centers (Freitas, 1991), they should be the first group evaluated for implementing an internal monitoring plan.

\section{ACKNOWLEDGEMENTS}

The authors are grateful to Professor Henry Spitz, from the University of Cincinnati, for his kind contribution on reviewing this paper.

\section{RESUMO}

A manipulação de fontes abertas em Serviços de Medicina Nuclear envolve riscos de exposição externa e contaminação interna. O plano de proteção radiológica das Instalações licenciadas pela CNEN deve incluir a avaliação de tais riscos e propor um programa de monitoração individual de forma a controlar as exposições e garantir a manutenção das condições de segurança radiológica. As recomendações da AIEA apresentadas no Safety Guide RS-G-1.2 sugerem que seja implementado um programa de monitoração interna do trabalhador sempre que houver possibilidade da contaminação interna conduzir a valores de dose efetiva comprometida anual igual ou superior a $1 \mathrm{mSv}$. Este trabalho apresenta a simulação da aplicação de tais critérios para os radionuclídeos mais utilizados na área de Medicina Nuclear, levando-se em consideração as condições usuais de manipulação das fontes e as faixas de atividade autorizadas pela CNEN. Conclui-se que a manipulação de iodo 131 para fins terapêuticos é a prática que apresentada maior risco de exposição interna dos trabalhadores, requerendo a adoção de um programa de monitoração interna por parte dos Serviços de Medicina Nuclear.

\section{REFERENCES}

Alves, C. E. G. R. (2004), Aspectos e Progressos do Programa de Inspeção em Serviços de Medicina Nuclear do Brasil. MSc Dissertation, Instituto de Radioproteção e Dosimetria, Rio de Janeiro, RJ, Brasil.

Bertelli1, L.; Melo, D. R.; Lipsztein, J.; Cruz-Suarez, R. (2008), AIDE: Internal Dosimetry Software. Radiat Prot Dosimetry., p. 1-10. 
Comissão Nacional de Energia Nuclear (CNEN). (1996), Requisitos de Radioproteção e Segurança para Serviços de medicina Nuclear. Norma CNENNE-3.05. Rio de Janeiro, CNEN, Rio de Janeiro.

Comissão Nacional de Energia Nuclear (CNEN). (2005), Diretrizes Básicas de Radioproteção. Norma CNEN-NE-3.01. CNEN, Rio de Janeiro.

Dantas, B. M.; Lucena, E. A.; Dantas, A. L. A.; Araújo, F.; Rebelo, A. M. O.; Terán, M.; Paolino, A.; Hermida, J. C.; Rojo, A. M.; Puerta, J. A.; Morales, J.; Bejerano, G. M. L.; Alfaro, M.; Ruiz, M. A.; Videla, R.; Piñones, O.; González, S.; Navarro, T.; Melo, D.; Cruz-Suárez, R. (2007), A protocol for the calibration of gamma cameras to estimate internal contamination in emergency situations. Radiat Prot Dosimetry. , 127, 253-257.

Freitas, A.C. (1991), Monitoração de Tecnécio-99m e Iodo-131 em Serviços de Medicina Nuclear Visando a Redução da Dose Interna em Profissionais Ocupacionalmente Expostos. MSc Dissertation. Universidade do Estado do Rio de Janeiro. RJ, Brazil. International Atomic Energy Agency (IAEA). 1999). Assessment of Occupational Exposure due to Intakes of Radionuclides - IAEA Safety Guide No.RS-G-1.2, IAEA, Vienna.
Lucena, E. A.; Rebelo, A. M. O.; Araújo, F.; Sousa, W. O.; Dantas, A. L. A.; Dantas, B. M.; Corbo, R. (2007), Evaluation of internal exposure of nuclear medicine staff through in vivo and in vitro bioassay techniques Rad Prot Dosimetry, 127, 465-468.

Melo, D. R.; Cruz Suarez, R.; Rojo, A. M.; Dantas, B. M.; Julião, L. M. C.; Serdero, N.; Videla, R.; Puerta, J. A.; Lopez, G.; Alfaro, M. M.; Gonzáles, S.; Hermida, J. C.; Navarro, T. (2007), Harmonization of internal dosimetry procedures in latin américaARCAL/IAEA Project. Radiat Prot Dosimetry, 127, 325-328.

Vidal, M. V. S.; Dantas, A. L. A.; Dantas, B. M. (2007), A methodology for auto-monitoring of internal contamination by ${ }^{131} \mathrm{I}$ in nuclear medicine workers. Radiat Prot Dosimetry, 125, 483-487.

Received: August 21, 2008; Revised: September 01, 2008; Accepted: September 03, 2008. 